\title{
Use of growth hormone in co-treatment with GnRH agonist long protocol in patients 40 years improves embryo quality?
}

\author{
Uso de hormônio de crescimento em co-tratamento com o agonista \\ do GnRH no protocolo longo em paciente de 40 anos melhora a \\ qualidade embrionária?
}

\author{
Macedo, JF., Gomes, LMO, Melo, KRB \\ Clinica Reproferty- São José dos Campos, SP, Brasil \\ Accredited Redlara center
}

\begin{abstract}
The human growth hormone plays a very important role in the final stages of oocyte maturation and embryogenesis, as well as for many other mammalian species. Patient 40 years, trying to become pregnant for 4 years: man with moderate oligozoospermia, five IVF cycles without success in other clinics. In 2009 the cycle recruited 14 oocytes, IVF was performed with embryo transfer, no pregnancy. Second fresh cycle fresh had chemical pregnancy. In the third the couple redid the tests, the husband was diagnosed with hepatitis $\mathrm{C}$, and in this cycle 3 embryos were transferred, without success. On the fourth cycle the patient performed $\mathrm{CGH}$, which accused trisomy, no transfer. In cycle $5 \mathrm{CGH}$ got one euploid embryo, and transfer was carried out but there resulted only chemical pregnancy. In cycle 6 embryos were subjected to conventional PGD and panel with 5 chromosomes, resulting in a single euploid embryo that was transferred and resulted in negative $\beta$-HCG. After 5 months the patient started treatment again with a long protocol and use of human growth hormone: 15 follicles were aspirated. ICSI was performed for all viable oocytes. All embryos which developed were subjected to PGD on day 3, resulting in 4 euploid embryos that were transferred and resulted in $\beta$-HCG positive. Although several articles suggest various protocols, there is not a standard. Thus, studies should continue to standardize that new protocol that may result in increased chances of successful pregnancy.
\end{abstract}

Keywords: stimulation, human growth hormone, fertility, PGD, time lapse.

\section{RESUMO}

O hormônio de crescimento humano desempenha um papel muito importante nos estágios finais de maturação dos oócitos e embriogenese, assim como para diversos outros tipos de espécies de mamíferos. Paciente de 40 anos, tenta há 4 anos engravidar, indicação: oligozoospermia moderada, realizou 5 tentativas de FIV sem sucesso em outras clínicas. Em 2009 obteve 14 óvulos, foi realizada a FIV e transferência embrionária, não engravidou. No segundo ciclo à fresco ocorreu apenas ocorreu gravidez química. Na terceira o casal refez os exames, marido foi diagnosticado com hepatite $C$, nesse ciclo foram transferidos 3 embriões, sem sucesso. $\mathrm{Na}$ quarta tentativa a paciente realizou o $\mathrm{CGH}, \mathrm{O}$ qual acusou trissomia, não houve transferência. No $5^{\circ}$ ciclo realizou CGH e obteve 1 embrião euplóide, a transferência foi realizada, porém obteve somente gravidez química. No $6^{\circ}$ ciclo os embriões que evoluíram foram submetidos ao PGD convencional com painel de 5 cromossomos, resultando em um único embrião euplóide, transferido e $\beta$-HCG negativo. Após 5 meses a paciente iniciou novo o tratamento com protocolo longo e uso de hormônio de crescimento humano. Foram aspirados 15 folículos. Realizou-se a ICSI para todos os oócitos viáveis. Todos os embriões que evoluíram foram submetidos ao PGD no dia 3, resultando em 4 embriões euplóides, que transferidos resultaram em $\beta$-HCG positivo. Embora existam diversos protocolos, ainda não foi realizada uma padronização. Assim, os estudos devem continuar para que se padronizem novos protocolos que venham a resultar em aumento das chances de sucesso da gravidez.

Palavras-chave: Estimulação, hormônio de crescimento humano, fertilidade, PGD, time lapse.

\section{INTRODUCTION}

Since the development of contraception in the 1960s, women have been able to delay childbearing. Oocyte maturation relies on a poorly-understood, complex cascade involving the coordination of both nuclear e cytoplasmic changes (De Santis et al., 2005). After approximately 30 years of age, a woman's fertility decreases (Menken et al., 1986), thereby, a combination of declining birth rates, reduce natural fecundity with increase age, has resulted in a steady increase the number and proportion of women aged $\geq 35$ years seeking assisted reproduction (Alviggi et al., 2009).

The human growth hormone plays a very important role in the final stages of human maturation oocyte and early embriogenesis, as well as for several mammalian species. Growth hormone is reported to modulate the action of FSH on granulosa cells (Barecca et al., 1993). Human GH (rhGH) receptors are present in the cumulus cells, and both immature and germinal vesicle and mature metaphase II stage oocytes (Menezo et al., 2003). Low concentrations of hGH in follicular fluid are associated with fertilization failures, cleavage failure and poor embryonic morphology (Mendo$z a, 1999$ ). The use of hGH in the treatment of women with subfertility was first reported in the early 1990s (Shoham et al., 1992) and since then its clinical use has been controversial. Recent studies have shown promising results in a randomized study of 100 women age $>40$ years, performing a co-stimulation with somatropin (8 IU / day), led a to significantly higher plasma and intrafollicular estradiol levels (Tesarik et al., 2005). The case is reported of a patient with poor quality embryos and showed a good development after use of growth hormone during ovarian stimulation.

\section{CASE REPORT}

Patient 40 years, trying to pregnant for 4 years, indicate: moderate oligozoospermia, performed 5 IVF without success in other clinics. The first performed in 2009 retrieved 14 follicles, oocytes fertilized were transferred, however not pregnancy occur. In the second performed with a fresh cycle occurred only chemical pregnancy. At the third performed the couple exams performed again, the husband was diagnosed with hepatitis $\mathrm{C}$ and in the cycle 3 embryos were transferred, without success. In the cyclo 4 performed, embryos were subjected at $\mathrm{CGH}$, which resulted in trisomy, embryo no transfer. In the cyclo 5 performed and 
embryos subjected at CGH resulted in 1 euploid embryo, the transfer was performed, however only obtained chemical pregnancy.

In our clinic patients performed cyclo 6, treatment with short cycle, 11 follicles were aspirated. ICSI was performed for all viable oocytes. All embryos (total of 6 ) were subjected to PGD on day 3, resulting in a single embryo euploid, which was transferred and resulted in negative $\beta$-HCG.

After 5 months the patient performed the treatment again, cycle 7 were performed in the same clinic with long cycle and use of human growth hormone (Saizen ${ }^{\circledR}$ ), 15 follicles were aspirated. ICSI was performed for all viable oocytes. All embryos ( 9 total) were subjected to PGD on day 3 resulting in 4 euploid embryos that were transferred and resulted in $\beta$-HCG positive.

\section{RESULTS}

\section{Cycle 6:}

Cycle 6 began with controlled ovarian stimulation was achieved with short cycle and administration of 225 IU recombinant follicle stimulating hormone (FSH) (Gonal- $\mathrm{F}^{\circledR}$, Serono, Geneva, Switzerland). During day 6 to day 10, began the administration of 225 IU antagonist of gonadotropin releasing hormone (GnRH) antagonist (cetrorelix, Cetrotide ${ }^{\circledR}$, Serono, Geneva, Switzerland). The patient's hormone levels on days 7 and 10 of stimulation were: a) progesterone: $0.236 \mathrm{ng} / \mathrm{mL}$ and $0.425 \mathrm{ng} / \mathrm{ml}$, b) Estradiol E2: 509.50 $\mathrm{pg} / \mathrm{mL}$ and $887.80 \mathrm{pg} / \mathrm{ml}$.

On day 10 were administered $250 \mathrm{mcg}$ of recombinant choriogonadotropin alfa (rhCG) (Ovidrel ${ }^{\circledR}$, Serono, Geneva, Switzerland). Oocytes aspiration occurred $34 \mathrm{~h}$ after administration of rhCG.

In cycle 6,11 follicles were aspirated; oocytes were maintained in medium buffered MOPS (G-Mops ${ }^{\mathrm{m}}$, Vitrolife $A B$, Gothenburg, Sweden) and coated with mineral oil (Oil Lite ${ }^{\circledR}$, Life Global, USA) for 2-3h before removal of cumulus cells. The cumulus cells were removed after being in contact with the G-Mops. Cumulus cells which remained were mechanically removed. The morphology of the oocytes was assessed using a Nikon Diaphot inverted microscope (Eclipse TE 300; Nikon ${ }^{\circledR}$, Tokyo, Japan) with contrast modulation system of $400 \times$ under Hoffmann magnification before sperm injection (3-4 hs after aspiration). Oocytes were classified as follows: 1 in metaphase I (MI), 7 in metaphase II (MII), 1 in prophase 1 (P1), 1 and 1 atresic empty. Oocytes that released first polar body were used for ICSI. The oocytes in PI and MI did not development and 1 MII oocyte that was also not development after intracytoplasmic sperm injection. The oocytes were transferred to a plate micro-injection prepared with 4 $\mu$ droplets of fertilization medium (Global Total ${ }^{\circledR}$ for fertilization, Global Life, USA) and covered with mineral oil (Oil Lite $^{\circledR}$, Global Life, USA) in workspace heated at $37 \pm 0.5^{\circ}$ $C$ in the inverted microscope was performed for ICSI and these oocytes were kept in vertical incubators (K-system, Birkerod, Denmark) with humidified $6 \% \mathrm{CO}_{2}$ at $37^{\circ} \mathrm{C}$. Approximately 16 hours after ICSI, fertilization was confirmed by presence of two pronuclei and appearance of a second polar body. Embryonic development was evaluated in a conventional way (reviewed in pre-determined by embryologist). Embryos reaching at least the 5-cell stage on day 3 of development were biopsied by laser zone drilling using an Infrared Diode Laser (Octax Laser Shot System, MTG, Bruckberg, Germany), withdrew the material necessary to biopsy and returned to culture embryos; only one blastomere was removed by embryo. Then samples were fixed on slides by the method $\mathrm{HCl}$ / Tween 20 as described by Dumoulin et al., 2005.

In situ hybridization was performed using the following probes for chromosomes $X, Y, 13,18$ and 21 (PGT Multivision Probe Panel; Vysis, Downers Grove, USA). FISH procedure was carried out as described by Van de Velde et al. 2000 . The results were analyzed using a fluorescence microscope, embryos diagnosis were considered normal when two sex chromosomes or two chromosomes 13.18 band 21 were present. Some FISH procedure-related factors were responsible incomplete nuclei, covered with debris or nuclei without clear signal, the events were reported as failures FISH.

In this cycle all embryos (total of 6 ) were subjected to PGD on day 3 , resulting in a single embryo euploid. The transfer was performed on day 5 using a flexible catheter guided by transabdominal ultrasound. A single embryo was transferred and resulted in negative $\beta$-HCG.

\section{Cycle 7:}

After 5 months the patient performed again treatment with long cycle and use of human growth hormone (Saizen ${ }^{\circledR}$ ). During the day 1 at day 11 was used 5IU of leuprolide acetate (Lupron ${ }^{\circledR}$, Abbott Laboratories. Abbott Park, Illinois, USA), 300 IU of recombinant follicle stimulating hormone (FSH) (Gonal-F ${ }^{\circledR}$, Serono, Geneva, Switzerland) in days 1 at 8, Gonal-F ${ }^{\circledR}$ dose was reduced to 225 IU on days 9 and $10,150 \mathrm{IU}$ of alfa used lutropin (Luveris ${ }^{\circledR}$, Serono, Geneva, Switzerland) on day 1 at 8, 75 IU of alfa lutropin used in day 9 and 10 , , and day 1 at 10 used 4UI somatropin (Saizen ${ }^{\circledR}$, Serono, Geneva, Switzerland), in day 11 was administered $5 \mathrm{UI}$ of leuprolide acetate, $250 \mathrm{mcg}$ of recombinant choriogonadotropin alfa (rhCG) and 4UI somatropin, on the day 12 there was no administration of any medication. Patient's hormone levels in day 8 and 11 after stimulation were as follows: a) progesterone: $0.233 \mathrm{ng} / \mathrm{mL}$ and $0.892 \mathrm{ng} / \mathrm{ml}$, b) estradiol E2: $605.80 \mathrm{pg} / \mathrm{ml}$ and $2168.00 \mathrm{pg} / \mathrm{ml}$. Aspiration of oocytes occurred $34 \mathrm{~h}$ after administration of rhCG. Were aspirated 15 follicles; oocytes were maintained in medium buffered MOPS (G-Mops ${ }^{\mathrm{Tm}}$, Vitrolife $A B$, Gothenburg, Sweden) and coated with mineral oil (Oil Lite ${ }^{\circledR}$, Life Global, USA) for 2-3h before removal of cumulus cells. Sourrouding cumulus cells were removed after contact with the G-Mops, cumulus cells which remaining were mechanically removed. Morphology oocytes was assessed using a Nikon Diaphot inverted microscope (Eclipse TE 300; Nikon ${ }^{\circledR}$, Tokyo, Japan) with the system Hoffmann Modulation Contrast under $400 \mathrm{x}$ magnification before sperm injection (3-4hs after aspiration). We found 14 oocytes at metaphase II (MII) and 1 in metaphase I (MI). Oocytes that released the first polar body were used for ICSI. The oocytes were transferred to a plate microinjection especially suitable for monitoring embryonic development via time lapse (Primo Vision, Innovation Cryo, Szeged, Hungary). Plates were prepared with 4 droplets of fertilization medium (Global Total ${ }^{\circledR}$ for fertilization, Life Overall, USA) and covered with mineral oil (Oil Lite ${ }^{\circledR}$, Life Global, USA) in workstation heated at $37 \pm 0.5^{\circ} \mathrm{C}$ in inverted microscope, was performed ICSI for all oocytes. Approximately 16 hours after procedure, fertilization was confirmed by presence of two pronuclei and appearance of a second polar body, in this cycle only 1 oocyte MI not development and 4 oocytos MII not fertilized. Embryo development was evaluated on days 2 and 3 with use of technology "time-lapse", embryos were maintained in vertical incubators (K-system, Birkerod, Denmark) with humidified 6\% $\mathrm{CO}_{2}$ at $37^{\circ} \mathrm{C}$ for 3 days before biopsy. The captured images in Primo vision occurred every $25 \mathrm{~min}$. after moment of ICSI during three days of development. Embryos reaching at least the 5 -cell stage on day 3 of development were biopsied by the opening of the zona pellucida using laser (Octax Laser Shot System, MTG, Bruckberg, Germany), material necessary were removal to biopsy and returned to culture embryos. Embryos subjected PGD protocol as previously described. In this cycle all embryos (total of 9) subjected PGD on day 3, resulting in 4 euploid embryos, these embryos were transferred and resulted in positive $\beta-H C G$, clinical pregnancy was confirmed by conducting a ultrasonography and measurement of heartbeats of only one fetus.

\section{DISCUSSION}

In the study showed which human hormone growth can increase embryo quality. An increase patients's number older age who search assisted reproduction treatment is currently observed, biological age ovaries is more important than chronological age patient and can predict the outcome of assisted reproduction treatment (Alviggi et al., 2009). There are only a few reports where adjuvant growth 
hormone (GH) has been used in women with GH deficiency and obtained as a result of an increase in pregnancy rate (Giampietro et al., 2009). Literature reports that treatment with $\mathrm{GH}$ may increase the risk of glucose intolerance and the potential for pituitary/hypothalamic tumor recurrence cancer. However, there have been no reports in the few cases in the infertility literature with short term $\mathrm{GH}$ use (Molitch et al., 2011). Although there are several papers have suggest protocols has not been performed for standardization with effective time of use, dose and duration of treatment with $\mathrm{GH}$. Thus, studies should continue regarding the use of GH after stimulation with hMG for ovulation induction for new protocols to standardize that may result in increased chances of successful pregnancy.

\section{Corresponding Author}

Dr. José Fernando Macedo

Clinica Reproferty

Rua Santo Agostinho 179, Vila Adyanna.

São José dos Campos, SP, Brasil, CEP: 12243-800

Tel: 55- (12) 3941-5199

e-mail: fernandomacedo@reproferty.com.br

\section{REFERENCE}

Alviggi C, Humaidan P, Howles C M, Tredway D, Hillier SG. Biological versus chronological ovarian age: implications for assisted reproductive technology Reproductive Biology and Endocrinology. 2009, 7:101.

Barecca A, Artini P G, Del Monte P, Ponzani P, Pasquini P, Cariola $G$. In vivo and in vitro effect of growth hormone on estradiol secretion by granulosa cells. J Clin Endocrinol Metab. 1993; 77:61-7.

De Santis L, Cino I, Rabellotti E, Calzi F, Persico P, Borini A, Coticchio $\mathrm{G}$. Polar body morphology and spindle imaging as predictors of oocyte quality. Reprod Biomed Online. 2005; 11:36-42.

Dumoulin JC, Derhaag JG, Bras M, Van Montfoort AP, Kester $A D$, Evers JL, Geraedts JP and Coonen E. Growth rate of human preimplantation embryos is sex dependent after ICSI but not after IVF. Hum Reprod. 2005; 20:484-91.

Giampietro A, Milardi D, Bianchi A, Fusco A, Cimino V, Valle D, Marana R, Pontecorvi A, De Marinis L. The effect of treatment with growth hormone on fertility outcome in eugonadal women with growth hormone deficiency: report of four cases and review of the literature. Fertility and Sterility, 2009, 930.

Molitch M E, Clemmons D R, Malozowski S, Merriam G R, Vance $M$ L. Evaluation and treatment of adult growth hormone deficiency: an endocrine society clinical practice guideline. Journal of Clinical Endocrinology and Metabolism, 2011, 96, 1587-1609.

Mendoza C, Cremades N, Ruiz-Requena E, Martinez F, Ortega E, Bernabeu S, Tesarik J: Relationship between fertilization results after intracytoplasmic sperm injection, and intrafollicular steroid, pituitary hormone and cytokine concentrations. Hum Reprod. 1999, 14: 628-635.

Ménézo Y J, El Mouatassim S, Chavrier M, Servy E J, Nicolet B: Human oocytes and preimplantation embryos express mRNA for growth hormone receptor. Zygote. 2003, 293-297.

Menken J, Trussell J, Larsen U: Age and infertility. Science 1986, 1389-1394.

Owen E J, Shoham Z, Mason B A, Ostergaard H, Jacobs H S: Cotreatment with growth hormone, after pituitary suppression, for ovarian stimulation in in vitro fertilization: a randomized, double-blind, placebo-control trial. Fertil Steril. 1991, 1104-1110. Shoham Z, Homburg R, Owen E J, Conway G S, Ostergaard H, Jacobs H S: The role of treatment with growth hormone in infertile patients. Baillieres Clin Obstet Gynaecol. 1992, 267-281.

Tesarik J, Hazout A, Mendoza C. Improvement of delivery and live birth rates after ICSI in women aged $>40$ years by ovarian co-stimulation with growth hormone. Hum Reprod. 2005, 2536-2541.

Van de Velde H, De Vos A, Sermon K, Staessen C, De Rycke M, Van Assche E, Lissens W, Vandervorst M, Van Ranst $H$, Liebaers I, Van Steirteghem A. Embryo implantation after biopsy of one or two cells from cleavage-stage embryos with a view to preimplantation genetic diagnosis. Prenat Diagn. 2000; 1030-7. 